\title{
Socio psychiatric aspects of risperiodone
}

\section{Izabela Filov*1, Mare Tumbevska², Zivko Tumbevski², Laze Kuzmanovski ${ }^{2}$ and Dragan Janakievski²}

Address: ${ }^{1}$ Community Mental Health Prilep, F.Y.R.O.M and ${ }^{2}$ Mental Hospital Demir Hisar, F.Y.R.O.M

* Corresponding author

from International Society on Brain and Behaviour: 2nd International Congress on Brain and Behaviour

Thessaloniki, Greece. 17-20 November 2005

Published: 28 February 2006

Annals of General Psychiatry 2006, 5(SuppI I):S204 doi:10.1 I86/I744-859X-5-SI-S204

\section{Background}

Resocialisation process and techniques are the key point of interdependance of social psychiatry and psychopharmacology. Risperidon as a neuroleptic of new generation has shown more qulitative improvement in the extra hospital conditions than in conditions in hospital treatement.

\section{Materials and methods}

It was examined two groups of patients. The first group was from the 20 users in Community mental health, with diagnosis of schizophrenia and the second one was from the 20 patients, admited with diagnosis of schizophrenia in Mental hospital. On the two groups were applied PANSS and CGI quertionarie.

\section{Results}

In the first group, results were: more quickly reduction of the psychotic symptoms, application of low doses of Risperidon (1.5-3 mg per day), much more qualiative remission. Also, it was not necessary to apply another neuroleptics.

\section{Discussion}

A combination of new neuroleptics (Risperidon) and resocialisation techniques and process, esspeccilay in the extra hospital condition, is the treatment of choise in the present stage of knowledge. It helps a rational administration of psychotropics and use up patients vital existential potentialites.

\section{References}

I. Cadlovski G: Clinical Psychopharmacology 2003.

2. Kaplan H, Sadock B: Comprehensive Textbook of Psychiatry Third edition. 1998.

3. Hogarty GE, Anderson CM, Reiss DJ, et al:: Family psychoeducation, social skills training and maintenance therapy in the aftercare treatment of schizophrenia. Arch Gen Psychiatry 1991, 48:340-347.

4. Peuskens J, Risperidone Study Group: Br J Psychiatry 1995, 166:712-726. 